\title{
THE HIPPOCAMPAL CORTICOSTERONE RECEPTOR SYST EM OF THE HOMOZYGOUS DIABETES INSIPIDUS (BRATTLEBORO) RAT
}

\author{
E.R. DE KLOET and H.D. VELDHUIS \\ Rudalf Magnus Institute for Pharmacology. University of Utrecht, Vondellarn 6, 3521 \\ GD Utrecht (The Netherlands)
}

(Received September 11th, 1979)

(Revised version received November 2nd, 1979)

(Accepted November 2nd, 1979)

\section{SUMMARY}

The binding of $\left[{ }^{3} \mathrm{H}\right]$ corticosterone to hippocampal cytosol receptors of Brattieboro rats homozygols for diabetes insipidus (Ho-Di) and of normal Brattleboro rats (Ho-No) was investigated at $24 \mathrm{~h}$ after removal of the adrenals. The apparent maximal binding capacicy of the Ho-Di hippocampal corticosterone receptor system was about 30\% less than that of the Ho-No rats. Substitution of the vasopressin deficient rats with $1 \mathrm{E}$ pitressin tannate in oil partially restores the hippocampal corticosterone receptor level towards that of the coritrol animals.

The rat brain and in particular the hippocampus contains receptor sites for corticosterone, which is the principal adrenal glucocorticoid secreted by the adrenal crrtex $[9,13,15]$. The hippocampal corticosterone receptcr system is implicated in the physiological control of adaptive behavior $[1,3,4]$. Peptides relaied to ACTH, the endorphins, and the neuroks ypophyseal hormones have profound effects on learning and memory processes $[8,23]$. Such neuropeptides and corticosterone represent different but interacting hormonal systems involved in the control of these particular brain functions $[4,22]$. The concept of hormonal control of adaptive nehavior has emerged from a ?lassical endocrine approach: removal of the endocrine gland (pituitary or adrenal) or a genetically. determined lack of a particular hormone produced i: behavioral disturbance, which could be restcred by appropriate hormone replacement [21]. Fssentially this approach was used in the present stuay to analy.e the action of exogenous vasopressin on the hippocampal corticsterone receptor syste:n. The experiments were performed with homozygous diabetes insipidus rats (FIO-Di) of the Brattlebory strain, which have a hereditary lack in the synthesis of vasopressin [20].

Adult male Ho-Di rats $(200 \mathrm{~g})$ were substituted for one week daily with 
1E pitressin tannate in oil (a lysine vasopressin ersiched porcine pituitary extract, Parke Davis Co.) subcutaneously; the last administration $24 \mathrm{~h}$ prior to sacrifice. Ho-Di, pitressin tannate substituted Ho-Di and normal homozygous Brattleboro rats (Ho-No) were adrenalectorsized bilaterally. Twentyfour hours later the rats were perfused under Nembutal anesthesia via the heari, with saline. Hippocampal tissue was removed from the brain on ice [6], homogenized, centrifuged and assayed for $\left[{ }^{3} \mathrm{H}\right]$ corticosterone binding in cytosol as previously described [9]. The medium was $5 \mathrm{mM}$ Tris iuffer (Tris(hydroxymethyl)aminomethane) containing $1 \mathrm{mM}$ EDTA (ethylene diamine tetra acetate, disodium salt), $1 \mathrm{mM} 2$ mercaptoethanol and $5 \% \mathrm{gly}$ cerol adjusied to $\mathrm{pH}=\mathbf{7 . 4}$ with hydrochloric acid. $\left[{ }^{3} \mathrm{H}\right]$ Corticosterone (spec. act., $50 \mathrm{Ci} / \mathrm{mM}$, New kngjiand Nuclear) was added to the cytosol giving cortcentrations ranging from $1 \cdot 10^{-10} \mathrm{M}$ up to $2 \cdot 10^{-8} \mathrm{M}$. Aspecific binciing was determined in parallel incubations including a five hundred fold excess of unlabelled steroid. In another series of experiments using male Wistar rats $( \pm 200 \mathrm{~g})$ the binding of $\left[{ }^{3} \mathrm{H}\right]$ corricosterone $\left(2 \cdot 10^{-8} \mathrm{M}\right)$ was measured at various times after adrenalectomy. In these experiments the removal of the adrenals occurred either in the morning or in the evening.
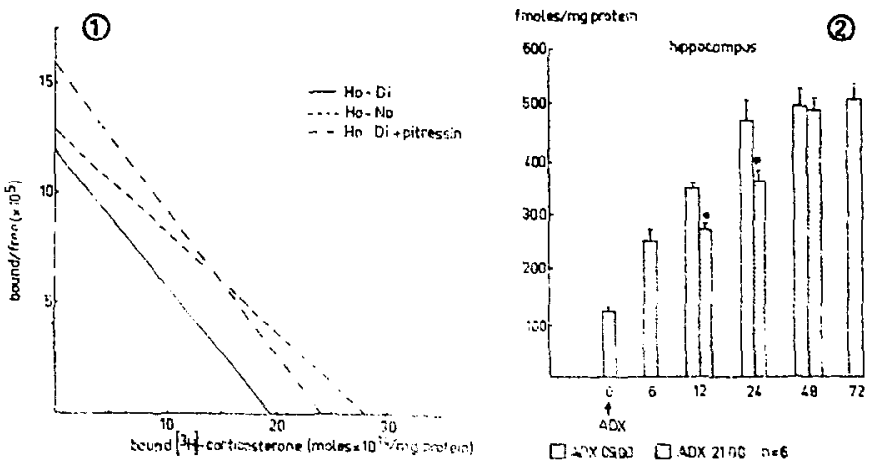

Fix. 1. Seatchard plot of bindine of $\left[{ }^{3} \mathrm{H}\right]$ corticontercro to tipposampai cytowol receptors. Scatchard analysiz was based on data of 10 weparate $i$ ias experimpnis. Each binding assay was performed with [ ${ }^{2} \mathrm{H}$ corticosterone con en to $2 \cdot 1 \mathrm{C}^{-\mathrm{t}} \mathrm{M}$. Aspecific binding rias determined in paraliel seriez $\mathrm{d}$ incutations including a five hundred fold excess of unlabeiled corticasterone. Anpurent binding constants

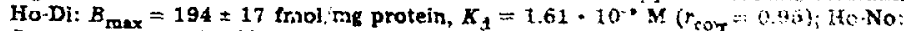

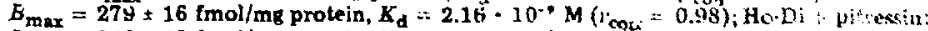

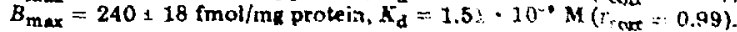

Fig. 2. Binding of [ ${ }^{\prime} \mathrm{H}$ ] corticosterone $\left(2 * 10^{\circ} \mathrm{M}\right)$ to hippocanupl sytorol receptors $2 i$ various times after adrenalectomy. Adrenkle vere removec either in the morninf (09:00) or evening (21;00). $t=0$ is the bindic $g$ in inte animale :neintaired until sacrifice under non-stressful condition. Data ax average of $r=6$ animals $\pm S . R . M$. 
Figure 1 shows that the apparent maximal binding caphesty calcallated aild analyses of the binding data via a Scatchard plot i.t aprorox. st1) lesk for Ho-Di $\left(B_{\max }=194 \mathrm{fmol} / \mathrm{mg}\right.$ protein $)$ than for Ho-No racs $\left(B_{\mathrm{m}+\mathrm{x}}=279(\mathrm{~m}, \mathrm{~s}) \mathrm{f}\right.$ $\mathrm{mg}$ protein). Daily administration of $1 \mathrm{E}$ pitressin tannate in oil tis cris wink to $\mathrm{Ho}-\mathrm{Di}$ rats caused a significantly increased binding capacity to a $1 \mathrm{c} / \mathrm{t}: \mathrm{l} \mathrm{H}$ :tween that of Ho-Di and Ho-No rats $\left(B_{\max }=240 \mathrm{fmol} / \mathrm{mg}\right.$ proteiri). Th: affinity constants for the corticosterone receptor binding dici not charif!: after pitressin administration $\left(K_{d}=1.5-1.6 \cdot 10^{-9} \mathrm{M}\right)$ but remained lowe? than that of $\mathrm{Ho}-\mathrm{No}$ animals $\left(K_{\mathrm{d}}=2.2 \cdot 10^{-9} \mathrm{M}\right)$. The tissues viste zemenve! from rats, which were adrenalectomized $24 \mathrm{~h}$ previously in ortar to deglete. the hip ocimpal corticosterone receptor system of endogenous hermone: Figure 2 shows for Wistar rats that as a function of time there is a tapid is:crease in available binding sites reaching a plateau after $24 \mathrm{~h}$. Hetween 24 and $72 \mathrm{~h}$ after adrenalectomy the binding increased only for about, $10 \%$. Kemoval of the adrenal in the evening (21:00), when plasma corticcsterons: levels are high, resulted after $24 \mathrm{~h}$ in a $25 \%$ lower [ ${ }^{\mathrm{d}} \mathrm{H}$ ] corticosterone binel. ing than when adrenalectomy was performed in the mcrning (09:00). The: circadian difference in amount of receptors gradually disappeared the next. day.

The present study shows that the capacity of the hippocampal corticosterore receptor system is substantially less for $\mathrm{Ho}-\mathrm{Di}$ than fer $\mathrm{Ho}-\mathrm{No}$ rais. This observation was made $24 \mathrm{~h}$ after adrenalectomy. Removal of the adrerials results in an increase in receptor sites available for binding of $\left[{ }^{3} \mathrm{H}\right]$. corticosterone and the binding reaches near maximal levels after $24 \mathrm{~h}$. 'This increase in available binding sites is in the first place due to the disappearance of endogenous corticosterone diring the first hours and possibly later on representative for newly synthetized receptor protein. In contrast to another report [14] the increased binding after adrenalectomy appeared not a biphusic, but a continuous process. The discrepancy may be related to pres:untical plasma corticosterone levels; the circadian variation in the amourit of retiptor sites measured up to $24 \mathrm{~h}$ after adrenalectomy is consonant with this uotion (Fig. 2 and ilef. 18). Chronic corticosterone administration via the drinking water or chronic stress cause decreased hippocampal cortic $n$ sterone receptor levels up to 4 days after adrenalectomy [19]. Dominant mice have a less active pituitary-adrenal system [5] than subordinates and also have an enhanced tissue uptake of $\left[{ }^{3} \mathrm{H}\right]$ corticosterone, which is indicative for a larger amount of corticosterone receptors [19]. These obselvations suggesi, that the amount of corticosterone receptors, meusured after adrenalectomy, primarily is under control of presurgical plasma concentrations of the proper hormone. The reduced post-adrenalectomy increase in $\left[{ }^{3} \mathrm{H}\right]$ corticosterone biuding observed in Ho-Di rats may be caused by a slower rate of disappearance of endogenous hormone. The metabolic half life of corticosterone in plasma of Ho-Di rats is, however, shorter than in that of Ho-No (12.7 min for Ho-Di and $19.5 \mathrm{~min}$ for Ho-No; de Kloet, unpublished obseration). In addition, Ho-Di rats have in general a reduced adrenal cortico- 
sterone secretion [17]. Therefore, the reduced post-adrenalectomy hippocampal binding capacity of Ho-Di rats ratner refms related to a sinaller preadrenalectomy binding capacity of the receptor system. Present methcdology does not allow, however, to estiruste the binding capacity in intact rats due to variability of receptor occupation with endogenous hormone.

This study shows that pitressin au gments the reduced amount of corticosterone receptors in Ho-Di rats. Such an action of the vasopressin enrichec? porcine pituitary extract may be secondarily to peripheral changes effectuater by the isormone treatment. The dose is sufficient to restore the abnormal water balance of these rats. Chronic pitressin treatment has been reperted to increase partially the hypothalamic CRH content and pituitary ACTH responsiveness of Ho-Di rats as well as admnal corticnsterone secretion towards the level of normal animals $[10,11,17]$. It could be angued that the enhanced adirenai corticosterone concentration influenzes the post-adrenalectomy increase in amount of hippocampal corticosteme receptors. However, elevated plasma corticosterone levels would diminish the capacity of the binding system, while pitressin treatment results in the opposite effect (Fig. $Z$ and Ref. 19).

Ho-Di rats have in seneral a hypouctive endocrine system $[2,12,16,17]$ and the nxluced amount of rec sptors may be a reflection of the genetic difference between tile two strains. There are, however, arguments to assign a specific role to vasopressin in the effect on neuronal processes involved in corticosterone action. A recent study from this laboratory showed tha: a singie vasoprissin injection restores a severe memory deficit of diabetes insipidus rats [ 25 j, sut the pituitary-drenal response accompanying the behavioral response in normal rats cannot the alsended by this treatment [24]. The sane absarvation was made with des'glycinamide ${ }^{3}$ anginine vasopressin (DG-AVP) a peptide lacking tire classical endocrine effecis of vasopressin, but maintaining the hehavioral activity [26). Preliminary obmetra-

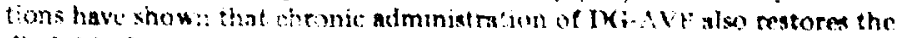

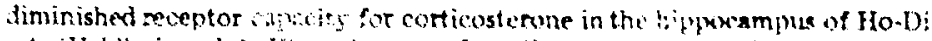

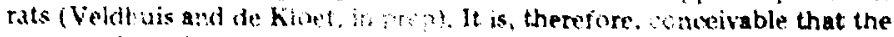

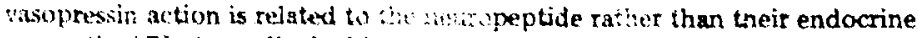
propwrties 17 . Acoordingly, hippixisman! reteptor scivity for corticosterone

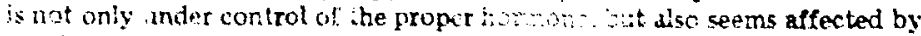
peptides such as rascpressin.

\section{ACKNOWLEDGENENT}

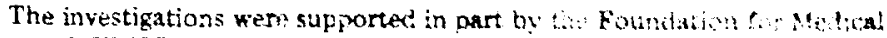

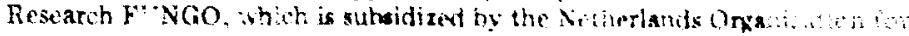
the Alvanement of Piero Ro ande (awO).

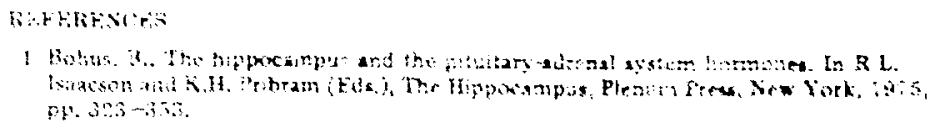


2 Bohus, B., Wimerama Greidanus, 'Tj.B. van and Wied, D. Ae, Behavioral and endocrine responses of sats with hereditary hypothalamic diabetes insipidus (Brattleboro strain), Physiol. Behav., 14 (1975) 609-6i5.

3 Bohns, B. and Kloet, E.R. de, Behavic:al effects of corticosterone related to putative glucocorticoid receptor properties in the rat brain, J. Endocrins', 1 $z, 1977$ ) $64 \mathrm{P}-65 \mathrm{P}$.

4 Bohus, B. and Kloet, F.R. de, Behavioral effects of ne: mespicts rolated to LPH and ACTH (endorphins, enkephalins, ACTH fragments) and corticosteroids. In M.T. Jones and M.F. Dallman (Eds,), Brain-Pituitary-Adrenocortical interredationships, Academic Press, Now York, 1979 , in press.

5 Brain, F.F. and Nowell, N.W., The eifects of differential groupinf cin endocrine function of mature male albino mice, Physiol. Behav., 5 (1970) 907-910.

6 Gispen, W.H., Schotman, P. and Kloet, E.R. de, Brain RNA and hypophysectomy; A topographical study, Neucoendocrinology, 9 (1972) 285-296.

7 Kloet, E.R. de, Veldhuis, H.D. and Bohus, B., Significance of netiropeptides in the control of co:ticosterone receptor activity in rai brain: In Proceedings 1st International Collocuium on Receptors, Neurotransmitters and Peptide Hormones, Capri, Italy, May 13-18, 1979, Raven Press, in press.

S Kloet, E.R. de and Wied, D. de, The brain as target tissue for hormones of pituitary origin; Behavioral and biochemical studies. In L. Martini and W.F. Ganong (Eds.), Fruntiers in Neuneadocrinology, Vol. 6, Raven Fress, New York, in press.

9 Kloet, E.R. de, Wellach, G. and McEwen, B.S., Differences in corticosterone and dexamethasone binding to rat brain and pituitiry, Endocrinology, 96 (1975) $612-623$.

10 Krieger, D.I'. and Liotts, A., Pituitary ACTH responsiveness in the vasopressin deîcient rat, Life Sci., 20 (1977) 327-336.

11 Krieger, D.T.. Liotta, A. and Brownstein, M.J., Corticotropin rele asing factor distriLution in normal and Ersttlebore rat brain and effect of desferentation, hypophysectomy and steroid treatment in normal animals, Endocrinology, 100 (1977) 22\%-23?.

12 McCann, S.M., Antunes-Rodrigues, J., Nallar, R. and Valtin, H., Jituitary function in the absence of rasoprestin, Endocrinology, 79 (15) jo) 1058-1064.

13 Mctwen, B.S., Interactions between hormones an? nerve tiss:e, t3ci. Arn., 235 (1976) $4 S^{\prime}-5 S$.

14 McFinen. B.S., Wallach, G. and Magnus, C., Corticosterone bir Jing to hippocampus: im rediate and delnyed infuenees of the shsenet ci adremal secretior. Brain Ros. 70 $1307+321-334$.

It MfeEwen. 8.S. Weis, J.M and Schwartz, L.S., Uptake of corticon wone by rat brain and its concentration by certatn limbie siructmes, Brain res. 10 (196.9) $2^{\prime 2} 7-24$ )

if Mc̈hring, B., Möhring, I.. Daud., G. and Haack, D., Potassium de iciency in rats with heleditary diabetes insipidus, Amer. J. Physiol, $22 ;(1974) 016-220$.

17 Mciung, J., Kohrs, G., Möhring, 3.. Petri. Mf. tionusy. E. nne Harek, D., E fects of px longe? vawpresin treatinent in Brattloboro sots with diabetes insipides, Amex. $d$. Ph-'sio', 234 (197S) F106-F111.

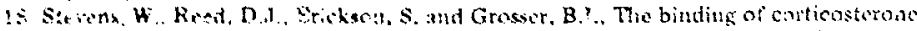

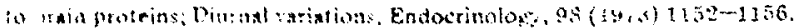

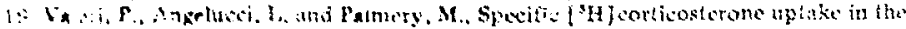

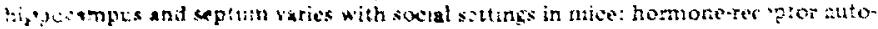

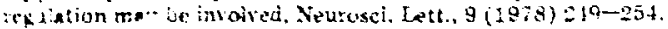

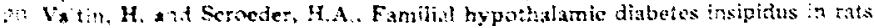

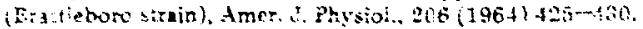

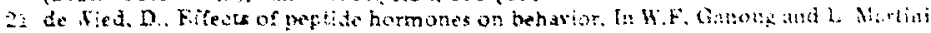

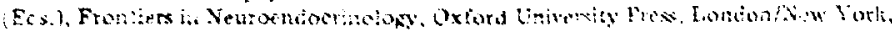

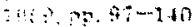


22 de Wied, D., Pituitary-adrenat aystem hormones ind, behavior, Acta Endocrinol. (Buppl.), 214 (1977) 0-18.

23 de Wied, D., Pituitury neuropeptides and hehavior, In K. Fure, T. Hökdelt end R. Luft (Eds.), Central Regulation of the Enriocrine Oyst om, Plenum Press: Nev York, 1979. pp. $207-314$.

24 de Wied, W., Bolsus, B., van Kre, J.M., Uthan, I. and van Wimerama Greidanus, M.B., Neurohy popbyseal homones and behavior. In A.M. Moses and L. Bh.se (Eze.), Neurohypophysis: 1 it. Conf. Neurohy poptyysis, Kez: Eizcayne, Morida. 1976, pp. 201-210.

25 de Wieć, D., Lohus, B, and van Wimerson a Greilenus, Tj.B., Memory deficit in rats with hereditary diahetes insipiciu, Brain Res., 85 (1975) 152-156.

26 de Wied, $\mathcal{D}_{\text {. }}$ Gireven, H.M., Lance, $\mathbf{S}$. and Witier, A., Disecciation of th.e behavioural and endocrine effect: of lysine vasopressir: by trjptie digestion, Brit. J. Pharmacol, 45 (1972) $118-122$. 